DOI: 10.17805/ggz.2019.3.2

\title{
Дивный, новый «цифровой мир»: \\ постирония как ценностная установка мировоззрения миллениалов ${ }^{*}$
}

\author{
А. В. Павлов
}

Институт философии РАН

В статье ставится проблема понимания цеенностных оснований «циифрового поколения» (миллениалов) как части общества. С этой целью автор рассматривает, каким образом в Интернете реализуется «сочиальность», описывает увлеченность миллениалов новейшими технологиями, сравнивает по нескольким критериям два поколения - «X» $u$ «Y» (миллениалов). Далее предлагается осторожная гипотеза: если культура постмодерна предполагала всепоглощающую иронию (главная мировоззренческая установка «поколения $X »)$, то новая культура во многом продуцирует и отражает постиронию. Именно последнюю автор статьи пытается описать как ключевой принци ценностных основ миллениалов. В тексте также утверждается, что «постирония», ставщая популярной в России, не имеет ничего общего с тем, что стали понимать под термином в западном мире. Автор говорит о постиронии в академическом (западном) значении.

Ключевые слова: миллениаль; Интернет; популярная культура; сочииальная теория; постмодерн; ирония; постирония; ценностные основы общества

\section{Brave New "Digital World": Postirony as a Value System of Millennials' Worldview}

A. V. Pavlov

Institute of Philosophy, Russian Academy of Sciences

The article raises the problem of understanding the value bases of the "digital generation" (millennials) as a part of the society. In pursuing this aim, the author analyzes how the "sociability" is realized on the Internet, describes millennials' enthusiasm for new technologies, compares two generations $-X$ and $Y$ (mil-

\footnotetext{
* Статья подготовлена в рамках работы по Программе фундаментальных исследований РАН «Многофакторные вызовы и риски перехода к новому этапу научно-технологического и экономического развития России: фундаментальные и прикладные проблемы». The article was prepared as part of the work on the Fundamental Research Program of the RAS "Multifactor Challenges and Risks of Transition to a New Stage of the Scientific, Technological and Economic Development of Russia: Fundamental and Applied Problems”.
} 
lennials) - by several criteria. Further, a cautious hypothesis is proposed: If the culture of postmodernism implies an all-consuming irony (the main worldview paradigm of Generation $X$ ), then the new culture produces and represents mainly postirony. The author tries to describe the latter as a key principle of millennials' axiological foundations. The text also argues that "postirony", which has become popular in Russia, has nothing in common with what has become the meaning of the term in the West. The author speaks about postirony namely in the academic (Western) meaning.

Keywords: millennials; Internet; popular culture; social theory; postmodern; irony; postirony; value bases of the society

\section{ВВЕДЕНИЕ}

Это правда, что мы, с одной стороны, продолжаем рассуждать об эпохах в соответствии со знаковыми мировыми событиями. Так, английский историк Эрик Хобсбаум определил ХХ век как «короткий», поместив его в хронологические рамки между 1914 и 1991 годами. Но, с другой стороны, мы также меряем эпохи в соответствии с резким скачком в технологиях - появление книгопечатания, фабричного производства, вытеснившего мануфактуры, возникновение и развитие электричества, наконец, распространение радио, телевидения, Интернета. Символическое начало XXI в. можно отсчитывать с беспрецедентного для западной цивилизации события - 11 сентября 2001 г. Но, возможно, куда более важной характеристикой нового столетия можно считать развитие и использование Интернета и в целом распространение того, что британский урбанист Адам Гринфилд назвал «радикальными технологиями». Проблема в том, что эти технологии развиваются так быстро, что общество едва успевает подстраиваться под них, обнаруживая все новые и новые практики и проблемы, требующие своего описания. За этим развитием не всегда просто разглядеть новые смыслы социальной жизни, если мы вообще вправе рассуждать о «социальном» в эру Интернета. Разумеется, ответ на вопрос, что мы можем сказать об обществе в новую эпоху, не только сложный, но также и широкий. И поэтому в настоящем исследовании я бы хотел сосредоточиться на одной очень важной, как мне кажется, конкретной теме.

Дело в том, что до недавнего времени вопрос определения поколений был куда более ясным, чем сегодня. У поколения был не просто голос, который звучал главным образом в культуре и медиа, но также и свои аналитики, работавшие с эмпирическими данными, будь то опросы или продукты культуры. С возникновением Интернета каждый представитель поколения обрел свой голос и каждый стал вправе сам решать, кем и чем ему быть, равно как 
и выбирать язык описания своего поколения. Очень просто описать людей, родившихся после 1990 г., как «миллениалов» или как «цифровое поколение». Но что мы можем о них сказать по существу? Кроме того, что молодые люди сидят в гаджетах и не знают жизни без Интернета, есть ли у них какаято характеристика, которая могла бы позволить описать их уникальность в сравнении с другими поколениями? Грубо говоря, что мы можем сказать о ценностных основаниях их мировоззрения? Чтобы ответить на этот вопрос, я постараюсь последовательно осветить несколько тем - во-первых, вкратце рассказать о «социальной природе» Интернета; во-вторых, дать характеристику миллениалов, сравнив их с предшественниками («поколением Х»); втретьих, осторожно высказать гипотезу, что главной мировоззренческой характеристикой «цифровых аборигенов» можно считать постиронию. Сразу оговорюсь, что я рассуждаю не как социолог, но как социальный теоретик, т. е. работаю не с базами данных, но как наблюдатель социальных явлений. Более того, я хотел бы опираться на тезис Джеффри Александера о том, что социальную жизнь нельзя понять без культуры (Александер, 2013). Вот почему тема культуры будет на первом плане.

\section{«СОЦИАЛЬНАЯ ПРИРОДА» ИНТЕРНЕТА}

Интернет уже давно находится в фокусе внимания социальных ученых. Некоторые даже доходят до того, что рассматривают его как «имплицитную религию». Так, культуролог Карен Пярна считает, что Интернет, опираясь на религиозные идеи, внушал своим пользователям настоящую новую веру (Pärna, 2010). Эта концепция, однако, не отвечает на вопрос о социальности Интернета удовлетворительно. Непосредственно данную тему попробовал проработать социальный теоретик Герт Ловинк. Он полагает, что старая социальная теория не может помочь нам в том, чтобы понять суть происходящих социальных изменений в контексте распространения технологий, и поэтому пытается развить совершенно новую теорию Интернета. Ирония заключается в том, что сам он опирается на тезисы Жана Бодрийяра, которые сегодня нельзя признать такими уж свежими. В начале 1980-х гг. Бодрийяр эпатировал академию тем, что объявил о конце социального. Ловинк утверждает, будто бы главный тезис Бодрийяра в том, что в какой-то момент социальное утратило свою историческую роль и «схлопнулось» до медиа.

Это, однако, не совсем так. Бодрийяр предлагает три положения о конце социального. Во-первых, социальное никогда не существовало в качестве сущности, потому что сущность социального заключается в «символическом» (репрезентации) и, следовательно, оно представляет собой симулякр. Во-вторых, социальное существует и даже разрастается, но оно все равно 
остается реальным лишь в своей символической функции. При таком положении дел социальное возникает тогда, когда верхние классы начинают социализировать «остатки общества» (бедняков, маргиналов и т. д.). «Социализируя» все новые и новые слои населения, социальное разрастается вширь. Наконец, в-третьих, о чем и говорит Ловинк: когда-то социальное существовало, но теперь его нет. Поглотив / «социализировав» все общество, социальное превращается в «тотальность». Не имея реального референта, оно умирает в медийной симуляции (Бодрийяр, 2000).

В более точном описании доводы Бодрийяра имеют основание. Предположим, что классы, слои, прослойки или даже группы существуют. Вместе с тем, это не реальные группы, но лишь медийные конструкты, которые используют журналисты или ученые (тогда это академические конструкты). Чтобы класс или прослойка говорили сами за себя, они должны выступить толпой и заявить о своих требованиях. Конечно, мы можем говорить о том, что социальное являет себя на митингах или протестных акциях, но все равно подавляющее большинство людей воспринимают их исключительно через фильтры медиа, и потому эти группы не репрезентируют себя, но описываются кем-то еще. Во всяком случае, социальное до недавнего времени существовало лишь в активных медиа, т. е. тогда, когда пользователь поглощает контент и не имеет возможности взаимодействовать с ним. Тем самым социальное действительно «схлопнулось». Но так было до развития Интернета.

Ловинк предлагает переосмыслить социальное в новом контексте. В самом деле уже словосочетание «социальные медиа» подсказывают нам о том, что с новыми технологиями пришла и новая «социальность». Однако анализ теоретика не утешает: социальное не вернулось. Фактически размышления автора - это приговор, потому что новое «социальное никак не соотносится ни с Социальным Вопросом, ни с каким-либо намеком на социалистическое мышление или социализм как политическую программу» (Ловинк, 2019: 36). И хотя, как мы увидим, Ловинк не во всем прав, все же он схватывает важные вещи, которые не часто поднимаются в дискуссиях, ведущихся в рамках социальной теории. С точки зрения ученого, в новую эпоху социальное - не более чем коммуникация, «это коллективная способность представлять связанных субъектов как временный союз. Сила и важность того, что потенциально может значить общение со многими, многими же и ощущается» (там же: 32). Ловинк не прав в том, что социальные медиа - лишь коммуникация. Сегодня многие авторы обличают новых агентов капитализма (платформы), которые получают прибыль с прибыли старых агентов капитализма (реальные производители) (Срничек, 2019). Вместе с тем, исследователь очень тонко чувствует то, что сегодня общество превратилось в базу 
данных пользователей, а в самих социальных медиа не происходит ничего, кроме постоянной «трескотни».

Мы должны отдавать себе отчет в том, что позиция Ловинка - не единственная. Это правда, что в итоге Интернет многих разочаровал. Как правило, аналитики Интернета делятся на «технопессимистов» и «технооптимистов». Первые настаивают, что сеть лишает людей творческих способностей, самостоятельного мышления и т. д. Так, публицист Евгений Морозов выступает против солюционизма Кремниевой долины, предполагающего, что можно найти технологическое решение любой проблемы (Морозов, 2014). Культуролог Алан Кирби взглянул на Интернет под другим углом, заявив, что последний производит «псевдоаутистов» - людей, замкнутых в созданных ими же цифровых мирах (Kirby, 2009) ${ }^{1}$. Вторые видят в Интернете новые возможности для демократии или для культуры в целом. Скажем, культуролог Генри Дженкинс радостно приветствовал новые возможности, предоставляющие пользователям право самим производить контент и соучаствовать в творческом процессе создания любимых франшиз. Дженкинс даже думает, что политический опыт в онлайн-играх может оказаться полезным для юных граждан в будущем (Jenkins, 2006). Более умеренный оптимист — политический теоретик Джон Кин - возлагает большие надежды на цифровую «мониторную демократию» (Кин, 2015). Все эти примеры говорят лишь об одном: Интернет стал важнейшей частью жизни современного общества, и в нем мы наблюдаем, как позитивные, так и негативные моменты.

Мой главный тезис, если помнить о цели, которую я заявил, заключается в следующем. Ранее медиа диктовали людям вообще и поколениям в частности их образ и их ценности. Через книги, фильмы или глянцевые журналы. Конечно, люди сами выбирали себе того, кто будет говорить от их лица, но все же их активность была ограничена тем, станут ли они считать себя, скажем, «поколением Х» или нет. В эпоху Интернета все изменилось. Это правда, что, как настаивает Ловинк, Интернет «заставил всех трещать без умолку». Но в этой «трескотне» мы можем разглядеть содержательное ядро, чтото такое, что могло бы оказаться общим опытом для целого поколения. Скажем, если миллионы людей одной возрастной категории будут постоянно писать и говорить о Гарри Поттере, то это единство культурного потребления кое-что скажет об их мировоззрении и ценностях, которые они разделяют, поскольку выросли на морали, представленной в конкретном литературном источнике. Что же в таком случае мы можем сказать о «поколении Ү»?

\footnotetext{
${ }^{1}$ Подробнее о пессимистическом взгляде Кирби см.: Сафронов, 2019.
} 


\section{КТО ТАКИЕ МИЛЛЕНИАЛЬ}

Существует несколько научных подходов к поколенческому анализу, которые можно различать в соответствии с методологией различных дисциплин - менеджериальный, социологический, психологический и даже «публицистический». Первый ориентирован на прагматику: представители менеджмента описывают поколения таким образом, чтобы руководителям предприятий и компаний было проще управлять подчиненными, находить с ними общий язык, понимать их ценности. Социология в свою очередь работает с конкретными данными, фиксируя то, что характерно для того или иного поколения - отношение к алкоголю, дружбе, досугу, религии и т. д. Психологи пытаются понять общие проблемы поколения (что беспокоит возрастные группы, возможные причины усталости, депрессии и т. д.) и помочь в их решении. Публицисты, как правило, поскольку они не ученые, просто свободно оперируют терминами и описывают поколения так, как их видят, обвиняя молодых людей в тех или иных грехах или же возлагая на молодежь надежды. Однако существует также и культурологический подход. Пожалуй, последний единственный предлагает возможность обозначить поколения не путем перечисления дат рождений и их практик, но рассматривает сущностные характеристики поколений, предлагает их уникальное описание.

Скажем, даже термин «поколение Х» возник в культуре и благодаря культуре. Впервые понятие использовал журналист и писатель Дуглас Коупленд в одноименной книге, а визуальный образ поколению придал режиссер Ричард Линклейтер в фильме «Бездельник» (в музыке символом поколения стал стиль гранж) (Lee, 2010). «Поколение X» в своем роде уникально. Во-первых, именно после него последующие поколения стали называть буквами алфавита - Y (миллениалы) и Z (постмиллениалы). Во-вторых, «поколение $\mathrm{X»} \mathrm{оставило} \mathrm{большой} \mathrm{след} \mathrm{в} \mathrm{популярной} \mathrm{культуре,} \mathrm{само} \mathrm{будучи} \mathrm{про-}$ дуктом или даже «ребенком» популярной культуры. Достаточно назвать имена Квентина Тарантино, Кевина Смита, Ричарда Линклейтера, Мэтта Стоуна, Трея Паркера и т. д. Самое главное, что было отражено этим поколением в массовой культуре - это их ценности и в широком смысле «идеология». Помимо увлеченности масскультом представителей поколения объединяло нежелание строить карьеру, тем самым они отказывались от участия в «крысиной гонке» «отцов», а зачастую — вовсе не работали, проводя время в праздности. Отсюда другой ключевой термин описания поколения - «бездельники» (slackers). В лучшем случае молодые люди имели «странные» хобби (например, расследования убийства Кеннеди), в худшем - ничего не делали. По крайней мере, именно так нам репрезентируют «поколение X» фильмы 1990-х гг. «Бездельник», «Клерки», «Под кайфом и в смятении», 
«Реальность кусается», «Криминальное чтиво», если называть самые знаменитые.

Иными словами, помимо отношения к тем или иным проблемам или наличия каких-то ценностей у «поколения X» была «идеология» (смотреть телевизор и ничего не делать), и она была прекрасно репрезентирована средствами массовой культуры. При этом важно, что «поколение Х» было прежде всего западным феноменом. Однако молодые люди в России, читая модные журналы, в которых шла речь о текстах Дугласа Коупленда и т. п., идентифицировали себя с этим поколением. Т. е. именно с «поколения Х» стало возможно говорить о поколениях в глобальном смысле слова, по крайней меpe, в отношении западных и близких к ним обществ. Только в 1990-е гг. Россия смогла начать официально потреблять западную культуру и тем самым разделять ее ценности. Или же не разделять, что в свою очередь тоже может быть ярким признаком поколения - ненависть к Западу. И все же, как известно, граждане России стали с удовольствием потреблять продукты масскульта. Но речь не об этом, а о том, каким образом на контрасте с «поколением Х» выглядят миллениалы.

Прежде всего, стоит сказать, что термин «миллениалы» ввели Уильям Штраус и Нил Хау в 1987 г. Он обозначал людей, которые родились после 1981 г. и должны были окончить школу в 2000 г. (Howe, Strauss, Matson, 2000). Позже миллениалов стали называть «поколением Y», противопоставляя его «поколению Х». Как отмечает психолог Джин Твенге, головокружительная скорость технического прогресса привела к образованию очень большого разрыва между рожденными в 1980-х гг. и теми, кто появился на свет в 1990-е гг. (Twenge, 2017). Тем самым ключевым признаком водораздела между двумя поколениями можно считать технологии. В самом деле, если опираться на культурологический подход, то мы сможем увидеть прекрасную репрезентацию поколения в актуальной массовой культуре. Например, нам показывают миллениала в мультсериале «Гриффины». В восемнадцатом эпизоде шестнадцатого сезона миллениал изображен как зацикленный на гаджетах человек, который любит фотографироваться и выкладывать фото в Instagram и постоянно общается в социальных медиа. В телевизионном сериале «Измерение 404» в одном из эпизодов закадровый голос, представляя главного героя, начинает нарратив следующим образом: «Это последний самурай “поколения X” и сегодня он встретится со своим злейшим врагом миллениалами». Если главный герой - неряшливый бездельник в растрепанной одежде, то его племянница-миллениал и ее подружки постоянно сидят в телефонах и хотят пойти в кинотеатр не на старый культовый фильм, а на модный подростковый блокбастер в 3D. Иными словами, миллениалы 
изображаются как «цифровые аборигены», не представляющие себе жизнь без новых технологий.

Вместе с тем, существует некая трудность, которая касается весьма зыбких границ поколенческого анализа. Так, для Штрауса и Хау миллениалы — те, кто родились в промежуток 1981-2000 гг. Социолог Вадим Радаев считает, что это те, кто родились начиная с первой половины 1980-х и до конца 1990-х гг., т. е. те, кому к 2018 г. было от 18 и до 35 (Радаев, 2019: 10). В свою очередь Твенге уверяет, что все, кто родились в период с 1995 по 2012 г., - это новое поколение постмиллениалов, которое она предлагает называть «поколение I» или «iGen» (“I” - не только IPhone, но также и индивидуализм) (Twenge, 2017: 7-8). Очевидно, что она хочет первой описать новое, еще незнакомое поколение. Но правда заключается в том, что в плане отношения к технологиям миллениалы и «постмиллениалы» практически не отличаются, а даты их рождения очень сильно совпадают. Тем самым, кажется, пока что рано судить о том, что будет представлять собой «поколение Z», хотя этот термин категорически не устраивает Твенге. Однако в любом случае последняя хорошо описывает то поколение, о котором ведем речь мы: «Родившись в 1995 году или позже, они взрослели, ни на минуту не расставаясь с телефоном. Свою первую страничку в Instagram они завели раньше, чем перешли в старшую школу, и они совершенно не представляют себе жизнь без Интернета» (ibid: 2; перевод мой. - $A$. П.).

Британский урбанист Адам Гринфилд в своей книге «Радикальные технологии: устройство повседневной жизни», рассуждая о последних тенденциях в технике и ее влиянии на наши социальные практики, пишет: «Очень быстро смартфон вытеснил бумбокс, кассетный и CD-плеер и радиоприемник - все портативные устройства, которыми мы пользовались для доступа к новостям и развлечениям...» (Гринфилд, 2018: 24). Более того, смартфон для многих из нас «стал последним предметом, на который мы смотрим каждую ночь перед тем, как заснуть, и первым, за которым тянемся спросонья. Мы используем его, чтобы знакомиться с людьми, общаться, развлекаться и находить дорогу. С его помощью мы покупаем и продаем вещи. Мы полагаемся на то, что он зафиксирует места, в которых мы бываем, вещи, которые делаем, и людей, с которыми общаемся; мы рассчитываем на то, что он поможет нам убить время, заполнить остановки и паузы, которые некогда занимали такую большую часть нашей жизни» (там же: 21). И если старшее поколение может обходиться кнопочным мобильным или даже электронной почтой, не участвую в жизни социальных медиа, то относительно молодые люди предпочитают смартфоны. Дело, однако, не в самой технике. Но в чем же тогда? 


\section{ОТ ИРОНИИ К ПОСТИРОНИИ}

Итак, миллениалы поглощены социальными медиа, имеют критический взгляд на позицию активных медиа и сами производят контент, являясь «просьюмерами». Это правда, что традиционные медиа и прежние формы работы сохранились. Но на активные медиа ориентируются старшие поколения, а с автоматизацией и цифровизацией исчезают не только рабочие места, но и целые профессии. Впрочем, не все согласны, что даже это на что-то всерьез влияет, потому что, упраздняя прежние ставки, например, банки отвечают на данные вызовы тем, что создают больше отделений (Срничек, Уильямс, 2019). Самое главное: появляются новые «цифровые профессии», замечательно описанные социальным теоретиком Николаем Афанасовым (Афанасов, 2019: 49-53), и, в конце концов, цифровой мир становится настолько же реальным, как и сама «реальность». Эти новые профессии занимают как раз те люди, которые хорошо осваивают технологические новинки и уверенно чувствуют себя в цифровом мире. Например, многие компании и даже государственные учреждения создают SMM-отделы, чтобы не терять связи с существенной частью аудитории.

Поскольку ранее речь шла о противопоставлении «поколения $\mathrm{X»} \mathrm{и}$ «поколения Y», важно обозначить несколько категорий, по которым эти группы расходятся. Относительно активной политической позиции миллениалов есть вопросы. Так, они становятся похожи на своих предшественников — «слекеров» - тем, что проявляют свою политическую активность, сидя на диване, т. е. остаются «бездельниками» с Интернетом. Этот феномен получил название «слактивизм» (от англ. “slack” и “activism”) (Мартынов, 2012). Более того, Евгений Морозов, пренебрежительно называя миллениалов «птенцами “Матрицы”», возражая на то, что те якобы политически активны (чаще других распространяют новости и присоединяются к политическим кампаниям в сети), замечает: «Они лишь имитируют свое участие в общественной жизни, передавая гражданскую ответственность по цепочке своим друзьям в соцсети. Кто знает, может быть, у “сетевого поколения” и правда особый подход к образованию, труду и общественной жизни, но не стоит все-таки пока делать много шума из того, что может оказаться пустышкой» (Морозов, 2014: 82).

Но что если нам стоит искать ответ на вопрос не в политической плоскости, а в культурной? Ведь культура не просто шире политики, но чаще и ближе подавляющему большинству людей — в конце концов, все так или иначе принимают в ней участие хотя бы на уровне потребителей. Как и «поколение Х», миллениалы также любят массовую культуры, но для них массовая культура стала совсем иной, и их отношения к этой культуре - тоже 
иное. В этом, пожалуй, состоит мировоззренческая суть миллениалов. С одной стороны, массовая культура стала скоротечной, и теперь кумиры сменяются куда быстрее, чем то было в 1980-е и 1990-е гг. С другой стороны, иной стала основная мировоззренческая установка «цифровой молодежи». Так, критики эпохи постмодерна постоянно сетовали на то, что в массовой культуре доминирует ирония как безразличное отношение ко всем серьезным вещам. Но поскольку от постмодерна отказались еще в начале 2000-х гг. (Hutcheon, 2002), что-то должно было прийти на смену и иронии. Что же это? Тот же Ловинк подметил, что в сети «пафосному и расслабленному постмодернистскому безразличию как квазиподрывному типу поведения приходит конец. Потому что плевать на все тут так же бессмысленно, как и не плевать» (Ловинк, 2019: 32).

Ловинк не готов называть вещи своими именами, но, между тем, другие авторы хотя бы предложили язык описания новой мировоззренческой установки миллениалов. Как и Ловинк, они также считают, что место иронии заняло что-то совсем другое, но, в отличие от Ловинка, это другое более позитивное, хотя и ангажированное. Это постирония. Проблема в данном случае состоит в том, что в отечественном публичном пространстве сложилось неправильное понимание «постиронии». С одной стороны, это клише, пустое понятие без какого-либо содержательного наполнения. Так, в России термин стал популярным летом 2017 года после рэп-баттла Оксимирона и Гнойного («постирония» - важная часть творчества последнего), и первый пик поиска слова в Google приходится на конец августа 2017 г. Как замечает один пользователь, давший себе труд написать историю понятия в России, изначально постирония означала «состояние, при котором границы серьезности и иронии оказываются размытыми», но в итоге, попав в сеть и специальные сообщества, приобрела смысл абстрактных мемов, смешных лишь в силу своей абсурдности (Itssunset, 2018: Электронный ресурс). Важно, что все это не имеет отношения к постиронии в том виде, в каком она стала известна в западной научной мысли. Так, литературовед Ли Константину утверждает, что постирония - это своеобразный способ преодолеть постмодерн, т. е. его всепоглощающую иронию. Важно сказать, что постирония - не новая искренность и не отсутствие иронии. Как отмечает ученый, «сторонники постиронии не ратуют за банальный возврат к искренности - потому что не выступают с позиций антииронии - а скорее хотят сохранить постмодернистские критические озарения (в различных сферах), при этом преодолев их тревожные измерения» (Konstantinou, 2017: 88; перевод мой. - А. П.). Т. е., скорее, это некие стратегии в культуре, которые стремятся по-своему описать новую «структуру чувства» (Williams, 1977). В качестве примера Константину вы- 
деляет четыре таких стратегии - мотивированный постмодернизм, доверчивая метапроза, постироничный «воспитательный роман» и реляционное искусство.

Однако этим движение постиронии не ограничивается. Оно может сказываться в восприятии новых продуктов культуры. Например, миллениалы отдают предпочтение «теплым сериалам» (когда авторы предлагают зрителям смеяться вместе с ними, а не над чем-то), в то время как «холодные сериалы», предполагающие иронию, отстраненность, отсутствие позиции, уходят на второй план (Rustad, Schwind, 2017). Постирония может проявляться через любовь к новой литературе - в частности к творчеству Дэвида Фостера Уоллеса, ставшему синонимом постиронии (Timmer, 2010). Миллениалы также могут понимать и даже использовать иронию, однако она остается лишь одним из инструментов для работы с культурой или в общении в ситуации «коммуникационного изобилия». Более того, миллениалы проповедуют и самоиронию, часто обыгрывая поколенческие споры. Так, существует мем «тридцатилетний бумер», высмеивающий «ранних миллениалов» - тех, кто ностальгирует по популярной культуре 1990-х гг. (Качалин, 2018: Электронный ресурс). Сами миллениалы все больше начинают искать в культуре простоту, искренность, и именно они объявляют, что место постмодернизма заняло что-то другое. Вся эта новая «структура чувства» проявляет себя в социальных медиа - в самых различных формах и на самых разных площадках. Таким образом, постирония - сложное понятие, которое не отрицает иронию, но также предлагает смотреть на мир не безразлично, но серьезно, хотя и в некоторых - определенных - отношениях. И в отличие от «цинизма, который отталкивает зрителей от участия в политической деятельности» «поколения Х» (Грёнинг, 2012: 233), миллениалы сегодня не прочь встать с дивана и заявить о своей политической позиции, воспринимая ее всерьез и не относясь к ней «наплевательски».

\section{ЗАКЛЮЧЕНИЕ}

Однако это всего лишь гипотеза. Скромная и сдержанная попытка понять суть ценностных основ мировоззрения «цифрового поколения» и предложить язык описания этого мировоззрения. Впрочем, с уверенностью можно утверждать, что значение цифрового мира и технологий будет возрастать, а вместе с ними и будет увеличиваться значение поколения, которое лучше всего разбирается в этом мире и жизнь которого протекает именно там. Спустя какое-то время, вероятно, появится категория темпоральной периодизации типа «феодализма» или «капитализма», которая будет описывать новый исторический этап эволюции человечества. В любом случае именно новые 
поколения будут отвечать за будущее. Как еще в 1957 г. заметил председатель Мао, обращаясь к китайским студентам и практикантам в Москве: «Мир принадлежит вам и в то же время нам, но в конечном счете вам. Вы, молодежь, полны бодрости и энергии, находитесь в расцвете сил и подобны солнцу в восемь-девять часов утра. На вас возлагаются надежды... Мир принадлежит вам» (Мао Цзэдун, 2007: 170). Наша задача, как социальных теоретиков, заключается в том, чтобы понять, кто такая эта «молодежь», чтобы знать, кому именно принадлежит будущий мир.

\section{СПИСОК ЛИТЕРАТУРЫ}

Александер, Дж. (2013) Смыслы социальной жизни: культурсоциология / пер. с англ. Г. К. Ольховикова под ред. Д. Ю. Куракина. М. : Изд. и консалтинговая группа «Праксис». 640 с.

Афанасов, Н. Б. (2019) Свободное время как новая форма труда: цифровые профессии и капитализм // Galactica Media: Journal of Media Studies. T. 1. № 1. С. 43-61.

Бодрийяр, Ж. (2000) В тени молчаливого большинства, или Конец социального / пер. с фр. Н. В. Суслова ; ред. К. В. Жвакин. Екатеринбург : Издво Уральского ун-та. 95 с.

Грёнинг, С. (2012) «Южный Парк»: цинизм и другие постидеологические полумеры // Логос. № 2 (86). С. 215-233.

Гринфилд, А. (2018) Радикальные технологии: устройство повседневной жизни / пер. с англ. И. Кушнаревой ; под науч. ред. С. Щукиной. М. : Изд. дом «Дело» РАНХиГС. 424 с.

Качалин, Ф. (2018) 30 year-old boomer [Электронный ресурс] // Memepedia. 4 сентября. URL: https://memepedia.ru/30-year-old-boomer/ [архивировано в WaybackMachine] (дата обращения: 20.06.2019).

Кин, Дж. (2015) Демократия и декаданс медиа / пер. с англ. Д. Кралечкина ; под науч. ред. А. Смирнова. М. : Изд. дом Высшей школы экономики. $312 \mathrm{c.}$

Ловинк, Г. (2019) Критическая теория интернета / пер. с англ. Д. Лебедева, П. Торкановского. М. : Ад Маргинем Пресс ; Музей современного искусства «Гараж». 304 с.

Мао Цзэдун. (2007) Маленькая красная книжица / под ред. О. В. Селина. М. : Алгоритм. 448 с.

Мартынов, К. (2012) От слактивизма к республике: почему интернетреволюции становятся реальностью // Логос. № 2 (86). С. 19-27.

Морозов, Е. (2014) Техноненависть: как интернет отучил нас думать / пер. с англ. В. Гончарука. М. : Common Place. 116 с. 
Радаев, В. В. (2019) Миллениалы: как меняется российское общество. М. : Изд. дом Высшей школы экономики. 224 с.

Сафронов, Э. Е. (2019) Что будет вместо постмодерна? Диджимодернизм как культурная доминанта // Galactica Media: Journal of Media Studies. T. 1. № 1. C. 178-195. DOI: 10.24411/2658-7734-2019-00010

Срничек, Н. (2019) Капитализм платформ / пер. с англ. и науч. ред. М. Добряковой. М. : Изд. дом Высшей школы экономики. 128 с.

Срничек, Н., Уильямс, А. (2019) Изобретая будущее: посткапитализм и мир без труда. М. : Strelka Press. 331 с.

Itssunset. (2018) Постирония и абстрактные мемы. Как развивалась культура щитпостинга в рунете [Электронный ресурс] // Memepedia. 3 сентября. URL: https://memepedia.ru/kratkaya-istoriya-postironii/ [архивировано в WaybackMachine] (дата обращения: 28.06.2019).

Howe, N., Strauss, W., Matson, R. J. (2000) Millennials rising: The next great generation. N. Y. : Vintage Books. 415 p.

Hutcheon, L. (2002) The politics of postmodernism. 2nd edn. N. Y. ; L. : Routledge. x, 222 p.

Jenkins, H. (2006) Convergence culture: Where old and new media collide. N. Y. : New York University Press. xi, 308 p.

Kirby, A. (2009) Digimodernism: How new technologies dismantle the postmodern and reconfigure our culture. N. Y. : Continuum. vi, $282 \mathrm{p}$.

Konstantinou, L. (2017) Four faces of postirony // Metamodernism: Historicity, affect, and depth after postmodernism / ed. by R. van den Akker, A. Gibbons, T. Vermeulen. L. ; N. Y. : Rowman \& Littlefield. xiii, 245 p. P. 87102.

Lee, Ch. (2010) Screening Generation X: The politics and popular memory of youth in contemporary cinema. Farnham, England ; Burlington, VT : Routledge. $\mathrm{x}, 184 \mathrm{p}$.

Pärna, K. (2010) Believing in the Net: Implicit religion and the internet hype, 1994-2001 : Doctoral thesis. Leiden : Leiden University Press. ix, 203 p.

Rustad, G. C., Schwind, K. H. (2017) The joke that wasn't funny anymore: Reflections on the metamodern sitcom // Metamodernism: Historicity, affect, and depth after postmodernism / ed. by R. van den Akker, A. Gibbons, T. Vermeulen. L. ; N. Y. : Rowman \& Littlefield. xiii, 245 p. P. 131-146.

Timmer, N. (2010) Do you feel it too? The post-postmodern syndrome in American fiction at the turn of the Millennium. Amsterdam ; N. Y. : Rodopi. 388 p. 
Twenge, J. M. (2017) iGen: Why today's super-connected kids are growing up less rebellious, more tolerant, less happy - and completely unprepared for adulthood (and what that means for the rest of us). N. Y. : Atria Books. viii, 342 p.

Williams, R. (1977) Marxism and literature. Oxford ; N. Y. : Oxford University Press. 217 p.

Дата поступления: 28.06.2019 г.

\section{REFERENCES}

Alexander, J. (2013) Smysly sotsial'noi zhizni: kultursotsiologiia [The meanings of social life: A cultural sociology] / transl. from English G. K. Olkhovikov, ed. by D. Yu. Kurakin. Moscow : Praxis Publ. and Consulting Company. 640 p. (In Russ.).

Afanasov, N. B. (2019) Svobodnoe vremia kak novaia forma truda: tsifrovye professii i kapitalizm [Spare time as a new form of labor: Digital professions and capitalism]. Galactica Media: Journal of Media Studies, vol. 1, no. 1, pp. 43-61. (In Russ.).

Baudrillard, J. (2000) V teni molchalivogo bol'shinstva, ili Konets sotsial'nogo [À l'ombre des majorités silencieuses ou la fin du social / In the shadow of the silent majorities, or, the end of the social] / transl. from French N. V. Suslova ; ed. by K. V. Zhvakin. Yekaterinburg : Ural State University Publ. 95 p. (In Russ.).

Groening, S. (2012) "Yuzhnyi park": tsinizm i drugie postideologicheskie polumery [Cynicism and other postideological half measures in "South Park"]. Logos, no. 2 (86), pp. 215-233. (In Russ.).

Greenfield, A. (2018) Radikal'nye tekhnologii: ustroistvo povsednevnoi zhizni [Radical technologies: The design of everyday life] / transl. from English by I. Kushnareva ; ed. by S. Shchukina. Moscow : Delo Publishing House, RANEPA. 424 p. (In Russ.).

Kachalin, Ph. (2018) 30 year-old boomer. Memepedia, September 4. [online] Available at: https://memepedia.ru/30-year-old-boomer/ [archived in WaybackMachine] (accessed on 28.06.2019). (In Russ.).

Keane, J. (2015) Demokratiia i dekadans media [Democracy and media decadence] / transl. from English by D. Kralechkin ; ed. by A. Smirnov. Moscow : HSE Publ. House. 312 p. (In Russ.).

Lovink, G. (2019) Kriticheskaia teoriia interneta [Critical Internet theory] / transl. from English by D. Lebedev and P. Torkanovskiy. Moscow : Ad Marginem Press ; Garage Museum of Contemporary Art. 304 p. (In Russ.).

Mao Zedong. (2007) Malen'kaia krasnaia knizhitsa [The Little red book] / ed. by O. V. Selin. Moscow : Algoritm Publ. 448 p. (In Russ.). 
Martynov, K. (2012) Ot slaktivizma k respublike: pochemu internetrevolutsii stanoviatsia real'nost'iu [From slacktivism to republic: The reason why Internet revolutions come to fruition]. Logos, no. 2 (86), pp. 19-27. (In Russ.).

Morozov, E. (2014) Tekhnonenavist': kak internet otuchil nas dumat' [Technohatred: How Internet weaned us off of thinking] / transl. from English by V. Goncharuk. Moscow : Common Place Publ. 116 p. (In Russ.).

Radaev, V. V. (2019) Millenialy: kak meniaetsia rossiiskoe obschestvo [Millenials: How the Russian society changes]. Moscow : HSE Publ. House. 224 p. (In Russ.).

Safronov, E. E. (2019) Chto budet vmesto postmoderna? Didzhimodernizm kak kul'turnaia dominanta [What will happen instead of postmodern? Digimodernism as a cultural dominant]. Galactica Media: Journal of Media Studies, vol. 1, no. 1, pp. 178-195. (In Russ.). DOI: 10.24411/2658-7734-2019-00010

Srnicek, N. (2019) Kapitalizm platform [Platform capitalism] / transl. from English and ed. by M. Dobriakova. Moscow : HSE Publ. House. 128 p. (In Russ.).

Srnicek, N. and Williams, A. (2019) Izobretaia budushchee: postkapitalizm i mir bez truda [Inventing the future: Postcapitalism and a world without work]. Moscow : Strelka Press. 331 p. (In Russ.).

Itssunset. (2018) Postironiia i abstraktnye memy. Kak razvivalas' kul'tura shchitpostinga $\mathrm{v}$ runete [Postirony and abstract memes. How the culture of shit posting was developing on the Runet]. Memepedia, September 3. [online] Available at: https://memepedia.ru/kratkaya-istoriya-postironii/ [archived in Wayback Machine] (accessed on 28.06.2019). (In Russ.).

Howe, N., Strauss, W. and Matson, R. J. (2000) Millennials rising: The next great generation. New York : Vintage Books. 415 p.

Hutcheon, L. (2002) The politics of postmodernism. 2nd edn. New York ; London : Routledge. $\mathrm{x}, 222 \mathrm{p}$.

Jenkins, H. (2006) Convergence culture: Where old and new media collide. New York : New York University Press. xi, 308 p.

Kirby, A. (2009) Digimodernism: How new technologies dismantle the postmodern and reconfigure our culture. New York : Continuum. vi, $282 \mathrm{p}$.

Konstantinou, L. (2017) Four faces of postirony. In: Metamodernism: Historicity, affect, and depth after postmodernism / ed. by R. van den Akker, A. Gibbons, T. Vermeulen. London ; New York : Rowman \& Littlefield. xiii, 245 p. Pp. 87-102.

Lee, Ch. (2010) Screening Generation X: The politics and popular memory of youth in contemporary cinema. Farnham, England ; Burlington, VT : Routledge. $\mathrm{x}, 184 \mathrm{p}$. 
Pärna, K. (2010) Believing in the Net: Implicit religion and the internet hype, 1994-2001 : Doctoral thesis. Leiden : Leiden University Press. ix, 203 p.

Rustad, G. C. and Schwind, K. H. (2017) The joke that wasn't funny anymore: Reflections on the metamodern sitcom. In: Metamodernism: Historicity, affect, and depth after postmodernism / ed. by R. van den Akker, A. Gibbons, T. Vermeulen. London ; New York : Rowman \& Littlefield. xiii, 245 p. Pp. 131146.

Timmer, N. (2010) Do you feel it too? The post-postmodern syndrome in american fiction at the turn of the Millennium. Amsterdam ; New York : Rodopi. $388 \mathrm{p}$.

Twenge, J. M. (2017) iGen: Why today's super-connected kids are growing up less rebellious, more tolerant, less happy - and completely unprepared for adulthood (and what that means for the rest of us). New York : Atria Books. viii, $342 \mathrm{p}$.

Williams, R. (1977) Marxism and literature. Oxford ; New York : Oxford University Press. 217 p.

Submission date: 28.06.2019.

Павлов Александр Владимирович - кандидат юридических наук, ведущий научный сотрудник сектора социальной философии Института философии РАН. Адрес: 109240, Россия, г. Москва, ул. Гончарная, д. 12, стр. 1. Тел.: +7 (495) 697-98-93. Эл. адрес: ale-pavlov@yandex.ru

Pavlov Aleksandr Vladimirovich, Candidate of Law, Leading Research Fellow, Department of Social Philosophy, Institute of Philosophy, Russian Academy of Sciences. Postal address: Bldg. 1, 12 Goncharnaya St., 109240 Moscow, Russian Federation. Tel.: +7 (495) 697-98-93. E-mail: ale-pavlov@yandex.ru

\section{Для ичитирования:}

Павлов А. В. Дивный, новый «цифровой мир»: постирония как ценностная установка мировоззрения миллениалов [Электронный ресурс] // Горизонты гуманитарного знания. 2019. № 3. C. 16-31. URL: http://journals. mosgu.ru/ggz/article/view/1042 (дата обращения: дд.мм.гггг). DOI: 10.17805/ ggz.2019.3.2 